\title{
Úpadek průmyslového Detroitu: odbory a globální výzvy
}

\section{Frank Hammer - Marek Hrubec}

Rozhovor Marka Hrubce s Frankem Hammerem, exprezidentem Odborového svazu zaměstnanců v automobilovém průmyslu (UAW - Regionu 909) v Michiganu v USA. Hammer pracoval dvaatřicet let v General Motors v Detroitu, v roce 2007 odešel do důchodu. Je spoluzakladatelem Autoworker Caravan, advokátního sdružení aktivních i penzionovaných zaměstnanců v automobilovém průmyslu, kde působí dodnes. Marek Hrubec vede Centrum globálních studií při Filosofickém ústavu v Praze.

M. Hrubec: Má první otázka bude osobní. Co Vás přivedlo k odborovému hnutí a jak jste se stal jeho předsedou? A co jste dělal předtím?

F. Hammer: Studoval jsem na Kalifornské universitě a chtěl jsem se stát architektem. $V$ té době existovalo silné studentské hnutí, které mě přivedlo k tomu, že jsem začal vidět svět jinak, než jak jsem ho nahlížel do té doby.

M. Hrubec: Studoval jste v Berkeley, v Los Angeles, nebo jinde?

F. Hammer: V Berkeley. Protože jsem byl zapojen do činnosti Hnutí za svobodu projevu, začal jsem více rozumět společnosti, v níž jsem žil. A tak jsem se rozhodl, že mým životním posláním nebude projektovat nové budovy, ale vytvořit sociální hnutí. Seznámil jsem se také s marxismem a dospěl jsem k názoru, že nejlepším způsobem, jak vybudovat sociální hnutí, bude obrátit se k zaměstnancům, dělníkům. Měl jsem diplom z Kalifornské univerzity a poté také z Michiganu, z Ann Arboru. Začal jsem pracovat v gumárně v Massachusetts, pak jsem se přestěhoval sem do Detroitu a v roce 1974 jsem získal místo v automobilce. Tato továrna se nacházela ve Warrenu v Michiganu, což je předměstí Detroitu, a byl jsem zde zaměstnán dvacet let. Původně to byla továrna na motory do vozů Chevrolet a pak se přeměnila v továrnu General Motors na výrobu převodovek. Zde jsem prvních šest let pracoval jako montážník. V roce 1981 jsem vstoupil do učení na potrubáře a stal jsem se potrubářem.

M. Hrubec: Jak jste zde začal organizovat odbory?

F. Hammer: Po několika letech, co jsem zde pracoval, jsem se spojil s dalšími dělníky, kteří byli také nespokojeni s tím, jak jsou zde odbory vedeny. Viděli jsme, jak podnik zneužívá dělníky, a proto jsme začali vydávat zpravodaj, jehož cílem bylo poučit dělníky o jejich právech, o smlouvách, o tom, jak se mobilizovat a prosazovat své názory a přání na odborových schůzích. A po určité době jsme vytvořili výbor podobně smýšlejících zaměstnanců. 
M. Hrubec: Kolik zaměstnanců přibližně tvořilo tuto skupinu? A kolik dělníků měla celá továrna?

F. Hammer: Původně jich v této skupině bylo kolem tuctu a v továrně pracovalo něco mezi 3500-4000 dělníků. Během vydávání zpravodaje, který vyvolával kontroverze, však rostl náš vliv. Nejprve se dělníci styděli, když si brali a četli náš zpravodaj, nebo pokud si ho už vzali, četli ho někde v ústraní, aby je nikdo neviděl, ale postupně nás začali respektovat. Vytvořili jsme distribuční sít' na všech třech směnách a začali mobilizovat dělníky, aby se zúčastnili odborové schůze. Tam se daly věci do pohybu a v roce 1984 jsme byli připraveni vést místní odbory a mnoho z nás také ve volbách vyhrálo. Získal jsem pozici předsedy pro oblast obchodu, což bylo jedna ze dvou nejdůležitějších pozic v lokálních odborech UAW, a od roku 1984 až do roku 1992 jsem zastupoval zhruba 3500 členů při jednáních s manažery. Z nich bylo 800 kvalifikovaných a zbytek nekvalifikovaných.

M. Hrubec: Z jakých etnických skupin tito členové pocházeli?

F. Hammer: To bylo zajímavé - byl to mix. Pokud jde o moji skupinu, 40 až 50 procent z nich byli Afroameričané, ale hodně bylo také Poláků a dělníků z východní Evropy. Mnoho dělníků bílé pleti také pocházelo z jižních států USA. Měli jsme také pár dělníků z Latinské Ameriky a několik dělníků arabských. Většinu dělníků tak tvořili běloši a černoši.

M. Hrubec: $Z$ jakého důvodu jste si vybral Detroit? Kvůli velké koncentraci dělníků a jejich zápasu?

F. Hammer: Jedním z důvodů, proč jsem přišel do Detroitu, bylo, že ve zdejším dělnickém hnutí $\mathrm{v}$ automobilovém průmyslu existovala poměrně silná militantní tradice, hlavně mezi Afroameričany. Na konci šedesátých let zde v odborech docházelo $\mathrm{k}$ výraznému boji proti rasismu a managementu. $\mathrm{V}$ té době existovala organizace, kterou vytvořili černošští dělníci, nazvaná „Liga černošských revolučních dělníků“, která organizovala nepovolené stávky. Její agitace měla přesah až do komunitního prostředí a mezi středoškolské studenty a podařilo se jí vytvořit v Detroitu hnutí. Její členy tvořili militantní Černí nacionalisté a také marxisté.

M. Hrubec: Bylo to podobné Malcomu X, který se také pokoušel legitimizo-vat násilí?

F. Hammer: Ano, mnoho prvků bylo ovlivněno Malcolmem X, částečně také osvobozeneckým hnutím v Africe či Martinem Lutherem Kingem. Cílem stávky bylo uzavřít továrnu a společnou solidární akcí dosáhnout změn. Černošští dělníci v těchto změnách uspěli, protože mnoho z nich získalo vedoucí pozice v odborech (UAW). Liga zanikla na počátku sedmdesátých let, ale její odkaz je pro nás stále 
důležitý, chceme-li se poučit z tehdejšího kontextu, tj. z militantní tradice v odborech UAW na konci šedesátých let a na počátku let sedmdesátých. Tato zkušenost mnoho z nás, včetně mne, inspirovala k nástupu do automobilky. Nastoupil jsem do továrny v době, kdy celé UAW byly na vrcholu, měly jeden a půl milionů členů. Od té doby jejich počet klesal.

M. Hrubec: Kolik z těchto členů bylo v Detroitu?

F. Hammer: Přibližně kolem stovky tisíc.

M. Hrubec: Předpokládám, že to byla největší koncentrace v USA?

F. Hammer: Ano, naprosto.

M. Hrubec: $A$ dnes?

F. Hammer: Dnes má UAW pouze čtyři sta tisíc členů. Je zřetelně vidět, jak počet ubývá.

M. Hrubec: $V$ době, kdy jste byl předsedou odborů, co pro vás bylo hlavním cílem a výzvou?

F. Hammer: V osmdesátých letech jsme čelili problémům s outsorcingem. Pokud chtěla firma přenést práci na nějaký jiný podnik, bojovali jsme proti tomu.

M. Hrubec: Myslíte outsourcing mimo USA?

F. Hammer: Ano, ale př́ležitostně také chtěli zadávat práci firmám, ve kterých nepůsobily odbory. V sedmdesátých letech se General Motors pokusily na jihu USA vytvořit továrny bez odborů, a mé odbory, UAW, proti tomu bojovaly a řekly: „Pokud chcete mít továrny v USA, musí tam působit odbory." A tento boj vyhrály.

M. Hrubec: To je výborné. Byl vztah mezi odbory a managementem vždy velmi konfliktní?

F. Hammer: Některé firmy a někteří odboroví vůdci se pokoušeli vytvořit partnerství mezi managementem a odbory. Také já sám jsem stál před touto otázkou a byl jsem si vědom její důležitosti. Ale pokud jsme spolupracovali s firmou, musely mít odbory možnost nezávislého hlasu a předkládat své vlastní požadavky.

M. Hrubec: Vrat'me se zpátky $k$ mé otázce týkající se globalizace a outsourcingu mimo území USA.

F. Hammer: Když vzniklo sdružení NAFTA (Dohoda o volném obchodu mezi USA, Kanadou a Mexikem), General Motors velmi výrazně zvýšily svou výrobu v Mexiku a hodně (amerických) výrobků bylo exportováno z Mexika do USA. 
M. Hrubec: Kdy zahraniční outsourcing začal? Bylo to již v osmdesátých letech za Reagana a jeho podpory neoliberální globalizace?

F. Hammer: Začalo to $v$ osmdesátých letech a zrychlilo se to se založením sdružení NAFTA v roce 1994.

M. Hrubec: Došlo k nějaké krizi v osmdesátých letech, nebo to více méně pokračovalo až ke krizi v letech 2007-2008?

F. Hammer: Bylo to postupné, ale automobilový průmysl také prošel cyklickými krizemi. Docházelo ke konfliktům v továrnách, které byly zavírány, ale konflikt se nepřenesl na úroveň města či státu. Vzpomínám si, že na počátku osmdesátých let jsem se zapojil do mnoha těchto konfliktů, jejichž cílem bylo ukončit zavírání některých jednotlivých továren. Protestovali jsme tak proti General Motors, když uzavřely továrny např́klad v Detroitu a v Mexiku. Ale jednotlivé továrny nezavíraly jen General Motors, ale i Ford a Chrysler. Mnoho dělníků bylo propuštěno a některé továrny byly zavřeny. Komunita, $v$ níž jsem žil, tak byla během osmi let totálně zdevastována. Mnoho lidí muselo opustit své domovy a odstěhovat se za prací jinam. A moji sousedé v roce 1988 se výrazně lišili od mých sousedů z roku 1980. Objevilo se zde mnohem více drog, i kriminalita se zvýšila.

M. Hrubec: Mohl byste uvést, jak byl úbytek dělníků ovlivněn automatizací?

F. Hammer: Za tu dobu, co jsem vedl odbory, firma nakoupila všechny možné druhy automatizovaných zařízení na výrobu převodovek. Pokoušeli jsme se vyjednat, kolik míst bude potřeba na jednotlivé operace. Záměrem vedení samozřejmě bylo eliminovat místa, my jsme se naopak snažili místa pro určitou část výroby zachránit. Za svého vedení jsem zastupoval 3500 dělníků a dnes jich daná továrna zaměstnává jen 400.

M. Hrubec: To je velký rozdíl. Rád bych se dozvěděl víc o úpadku Detroitu. Můžete ríci pár slov o Detroitu v době, kdy dosáhl svého populačního vrcholu, a o jeho stavu $v$ dnešní době?

F. Hammer: Detroit byl na vrcholu po druhé světové válce a na začátku padesátých let. $V$ té době se stal ekonomicky nejvíce prosperujícím městem v USA. Firmy stavěly své továrny také na jeho předměstích či v zemědělských částech státu. $\mathrm{V}$ této době, během Eisenhowerova prezidentství, existoval národní program na výstavbu dálniční sítě po celých USA, který byl masivně podporován $\mathrm{z}$ federálních zdrojů. Když se vybudoval dálniční systém, umožnilo to firmám opustit oblast Detroitu a odejít na sever či na západ. Dělníci, kteří byli schopni se odstěhovat za touto prací, a jednalo se především o bílé dělníky, si ji udrželi. Detroit tak do velké míry ztratil svoji průmyslovou výrobu. 
M. Hrubec: Kolik měl Detroit obyvatel v době svého vrcholu?

F. Hammer: Něco přes dva miliony.

M. Hrubec: $A$ od padesátých let tento počet klesal?

F. Hammer: Ano, od té doby klesal a nyní má něco málo pod sedm set tisíc obyvatel. Detroit je známý tím, že jeho městská oblast je velmi rozlehlá. V rámci jejích hranic se nachází 139 čtverečních mil půdy, většina domácností žila v rodinných domech. Oblast Detroitu se tak vyrovná městům jako San Francisko, Boston či Manhattan.

M. Hrubec: Dodnes jsou patrné negativní důsledky krize z let 2007-2008. Od té doby došlo v USA ke znatelnému poklesu automobilové výroby.

F. Hammer: K ohromnému poklesu. Desítky tisíc budov byly opuštěny a rozpadají se. Když projíždíte Detroitem, vidíte tyto válečné zóny destrukce. Stovky tisíc dělníků přišly o práci kvůli hypoteční krizi a krizi na Wall Streetu a trh s automobily dramaticky poklesl.

M. Hrubec: $A$ většina těchto aut se vyráběla v Detroitu a jeho okolí?

F. Hammer: Ano. A náhle došlo k nadbytku kapacit. Během krize v roce 2008 došlo k masivnímu propouštění a zavírání továren. Všechny tři automobilové společnosti vyráběly mnohem víc aut, než bylo možné prodat. A to vedlo k bankrotům.

M. Hrubec: Máte na mysli General Motors, Ford a Chrysler?

F. Hammer: Ano. Dříve zde působilo více společností, které však začaly zavírat své provozy již v padesátých letech, protože nebyly schopny konkurovat tzv. Detroitské trojce: General Motors, Fordu a Chrysleru.

M. Hrubec: Ty další společnosti zanikly?

F. Hammer: Ano. Jediné, kromě těch tří, které dnes fungují, jsou ty, které přišly z Evropy, Japonska a Koreje: Wolkswagen, Mercedes atd. Z amerických automobilek tak zůstaly jen ty tři, ostatní zanikly.

M. Hrubec: Navíc jsem četl, že bude možná docházet k jejich slučování.

F. Hammer: Ano, Chrysler se chce sloučit s General Motors. Hodně vykřikoval: „Chceme se sloučit, musíme se sloučit." Ale dnes jsou tyto tři firmy stále oddělené.

M. Hrubec: $A$ všechny působí v Detroitu?

F. Hammer: Ano, všechny mají své centrály v oblasti Detroitu. 
M. Hrubec: Rád bych se vrátil ke krizi z let 2007-2008. Zdá se, že to byla nejen ekonomická, ale i politická krize.

F. Hammer: Wall Street využil bankroty k tomu, aby provedl takové změny v automobilovém průmyslu, po kterých toužil již delší dobu, především co se týká dělníků v automobilovém průmyslu. Tak například bylo dělníkům od vypuknutí krize až do roku 2015 zakázáno stávkovat a ztratili mnoho výhod, které si v šedesátých letech vybojovali, jako bylo např. proplácení přesčasů nebo životních nákladů podle pracovních smluv. Během krize došlo k mnoha podobným redukcím, protože to měl Wall Street ve své agendě již velmi dlouhou dobu. A z úpadku General Motors a Chrysleru obviňoval dělníky a pracovní smlouvy, které si dříve prosadili.

M. Hrubec: Jak to souviselo s politikou? Četl jsem, že se politici státu Michigan rozhodli, že nedají Detroitu peníze z daní, tak jak tomu bylo dřive, a proto byl jeho propad horší, než kdyby je dostal.

F. Hammer: Tento př́stup, který pochází z Washingtonu, je politický, není jen ekonomický, a chce využít krize k tomu, aby zredukoval moc odborů. Především pravice na tom měla zájem. Musíte si uvědomit, že Detroit byl nazýván „městem odborů“ a v odborech byli hlavně černoši. Politikům se nelíbily odbory ani černoši v odborech.

M. Hrubec: Tvoří většinu populace Detroitu černoši?

F. Hammer: Ano, 85 procent obyvatel jsou černoši. Detroit je černošské město.

M. Hrubec: A dělníci v automobilovém průmyslu jsou většinou také Afroameričané?

F. Hammer: Čím dále na předměstí, tím jich je méně. Uzavírání továren má za následek také to, že dnes už skoro nejsou místa, kde by černí a bílí dělníci pracovali každodenně vedle sebe a osobně se znali.

M. Hrubec: Byli separováni profesně, nebo i lokalitou, v níž žijí?

F. Hammer: Dělníci v automobilce se rozlišovali na nekvalifikované a kvalifikované, mezi které historicky patřili běloši. Tak tomu bylo $v$ době, kdy jsem byl předsedou odborů. Když jste na konci směny stál před továrnou a díval se na parkoviště, viděl jste, že bílí dělníci směřují na sever a černí na jih. V Detroitu a celém jeho regionu je nejsegregovanější městská populace v rámci celých USA. Továrny tak byla místa, kde se spojili a společně pracovali. A jejich uzavíráním došlo k úbytku možností, kde by mohlo dojít k propojení bílých a černých dělníků. 
M. Hrubec: Mohl byste mi něco ř́ci o genderové problematice v automobilovém průmyslu? Předpokládám, že většina dělníkủ byli muži, nebo snad ženy také vykonávaly nějaké profese v tomto průmyslu?

F. Hammer: V sedmdesátých letech, krátce předtím, než jsem nastoupil, v celé továrně nebyla ani jedna žena. Ale $\mathrm{v}$ sedmdesátých letech byla také přijata řada federálních zákonů, které byly reakcí na silné hnutí za práva žen.

M. Hrubec: $V$ některých státech se toto hnutí objevilo již v letech šedesátých.

F. Hammer: To máte pravdu. Nové afirmativní zákony nařizovaly, aby továrny najímaly také ženy. Když jsem pak zastupoval továrnu, ženy tvořily šestinu pracovních sil.

M. Hrubec: I na montážní lince?

F. Hammer: Ano, např́íklad v provozech, kde se vyráběly sedačky či potahy a bylo tam potřeba šití atd. $V$ mé továrně, musím s potěšením říci, tvořily ženy až šestinu. To všechno bylo v důsledku bojů hnutí za ženská práva.

M. Hrubec: Brali to muži jako konkurenci?

F. Hammer: Bezpochyby. Převládal předsudek, že žena patří do domácnosti a že ženy berou práci mužům. Muž byl vnímán jako ten, kdo vydělává na chleba. Ale řekl bych, že poté, co se začaly najímat i ženy, začala tato stará ideologie mizet a najímání žen se stalo čímsi přirozeným.

M. Hrubec: Doufám, že nyní je už vnímáno jako normální, že jsou ženy zaměstnány $v$ automobilovém průmyslu.

F. Hammer: Ano, rozhodně.

M. Hrubec: Co se stalo se zaměstnanci, kteř́i ztratili práci? Našli si novou, jsou stále nezaměstnaní anebo opustili Detroit?

F. Hammer: Detroit nejprve ztratil jednu pětinu své populace.

M. Hrubec: Od krize v roce v 2007 ?

F. Hammer: Ne, mezi lety 2000 a 2010 . V těchto letech opustilo Detroit dvě stě tisíc lidí. Mnoho dělníků odešlo na jih, protože zde zahraniční společnosti postavily nové automobilové závody.

M. Hrubec: $O$ jaké státy se jmenovitě jedná?

F. Hammer: Nové továrny se stavěly ve státech Tennessee, Kentucky, Georgia, Alabama, Mississippi. Sem odešli dělníci, kteří opustili náš region. 
M. Hrubec: Ale ve srovnání s Detroitem tam lidé nejsou tak organizovaní, nejsou vodborech, jsou mnohem více izolovaní.

F. Hammer: Přesně tak. Nepracují v továrnách General Motors ani u Forda. $\mathrm{V}$ žádné z oněch továren nepůsobí odbory. UAW nebyly od poloviny osmdesátých let schopné se uchytit $\mathrm{v}$ žádné $\mathrm{z}$ továren na jihu. Jeden z podstatných důvodů tohoto stavu byl ten, že mzdové podmínky a struktura benefitů odpovídala, už když byly továrny na jihu postaveny, přibližně podmínkám v továrnách na severu, protože se tím chtělo zabránit vzniku odborů. Dělníkům se ř́́kalo: „Nepotřebujete odbory, protože dostanete benefity i bez nich." UAW tak nastaly těžké časy. Během bankrotů však vydala Obamova vláda nařízení, že máme-li se z této krize dostat, musí standardy továren na severu odpovídat standardům továren na jihu - a nikoliv opačně.

M. Hrubec: Byl na to vydán zákon?

F. Hammer: Byla to část dohody v době bankrotů - že UAW nebude vyžadovat v továrnách na severu vyšší standardy, než jsou v továrnách na jihu, kde odbory nepůsobily.

M. Hrubec: Takže z hlediska historie krok zpět.

F. Hammer: Ano, rozhodně to byl krok zpět. A pojistili si to ještě klauzulí o zákazu stávky. Ta byla zakázána až do roku 2015.

M. Hrubec: Jedná se o federální zákon a je stále platný?

F. Hammer: Bylo to federální nařízení pro automobilový průmysl General Motors a Chrysler. Reakcionáři řekli: „Nechme továrny zkrachovat, zhroutit a zavřít provozy." Chtěli se úplně zbavit odborů v automobilovém průmyslu.

M. Hrubec: Pokud zde ale nebudou žádné továrny, vláda nevybere žádné daně, takže stát si pohorší.

F. Hammer: Ano, ale to vykř̌ikovali reakcionáři z jihu, kam přicházela práce, a oni se nestarali o sever, o stát Michigan.

M. Hrubec: Co političtí reprezentanti Michiganu? Jak se k tomu postavili?

F. Hammer: Nemyslím si, že by se vládnoucí třída v USA nějak lišila ve svém postoji, zda tyto továrny zavřít či nikoli. Protože však výkřiky „Pojd'me je zavřít“ vyvolaly hodně povyku, Obama je zachránil, i když je přitom přiskř́ípl.

M. Hrubec: Tím, že nastavil horší pracovní podmínky?

F. Hammer: Správně. A předpokládalo se, že každý bude spokojen. 
M. Hrubec: Někteří dělníci tedy stále pracují ve zdejších továrnách, další odešli na jih, jiní zůstali v Detroitu, ale jsou nezaměstnaní, a další se pokusili přizpůsobit jinak. Mohl byste říci pár slov o této poslední skupině a říci, kde sehnali práci? Četl jsem, že také zorganizovaly nové komunitní projekty.

F. Hammer: Někteří zaměstnanci byli absorbováni například zdravotnictvím.

M. Hrubec: Soukromým, nebo veřejným?

F. Hammer: Oběma. V Detroitu máme velký zdravotnický komplex, který absorboval některé nezaměstnané. Ale přesto si musíme uvědomit, že míra nezaměstnanosti je v Detroitu velmi vysoká. V roce 2009 to bylo 50 procent!

M. Hrubec: To je opravdu velké číslo.

F. Hammer: Mezi mladými lidmi je nyní míra nezaměstnanosti pořád 40 procent.

M. Hrubec: Existuje nějaké státní nebo federální sociální zabezpečení nezaměstnaných?

F. Hammer: Existují dávky v nezaměstnanosti, které vyplácejí jednotlivé státy. Konzervativci neustále kritizovali sociální programy, protože prý podporují lenivost, a pokud prý dělníci dostávají vysoké dávky v nezaměstnanosti, nehledají si práci. Chtěli je proto vyhladovět. Tuto kritiku sociálních programů najdeme už v devadesátých letech za Clintonovy vlády. Republikáni hovořili o potřebě reforem sociálních programů a Clinton a Demokrati s nimi souhlasili. Zavedli omezení sociální podpory jen na pět let - poté na ni již nemáte nárok.

M. Hrubec: Sociální dávka je závislá na předchozí mzdě, anebo je stejná pro každého?

F. Hammer: Je nastavena podle míry chudoby.

M. Hrubec: Pokud lidé do pěti let neseženou práci, dávky se jim přestanou vyplácet a skončí jako žebráci na ulici? Kolik lidí to zasáhlo?

F. Hammer: Odhaduje se, že v Detroitu je přibližně dvacet tisíc bezdomovců.

M. Hrubec: Ale všiml jsem si, že v Detroitu je mnoho prázdných domů.

F. Hammer: Ano, je zde mnoho opuštěných domů - devadesát tisíc jich je prázdných.

M. Hrubec: $A$ bezdomovci je nemohou využít. To je paradox: lidé nemají kde bydlet a zároveň zde jsou prázdné domy.

F. Hammer: Ano, to jste vystihl dobře. Jsou zde squateři - lidé, kteří vstoupí do domů, napojí se na elektřinu a možná i na vodu. Je to však nelegální. Jsou tudíž 
vyhozeni a skončí zpátky na ulici. Dvacet tisíc bezdomovců při tolika volných domech. S tím, jak dnes krize pokračuje, očekává se, že šedesát tisíc rezidentů a rodin bude vystěhováno ze svých domovů, protože nejsou schopni zaplatit daň z nemovitosti. Mnoho dalších je odpojováno od dodávek vody, protože nejsou schopni za ni platit. A pokud k tomu dojde, sociální kurátoři jim odeberou děti, protože se o ně nemohou dobře starat. Když nemáte $v$ bytě vodu, musíte dát své dítě do opatrovnictví.

M. Hrubec: OSN prosadila právo na vodu jako mezinárodní právo. Volný přístup $k$ vodě pro každého, jinak by mohlo dojít k humanitární katastrofě.

F. Hammer: Ano, bude to humanitární katastrofa. Ale existuje právo na vodu. Dva zástupci OSN zde byli, aby vydali o této situaci prohlášení.

M. Hrubec: Existují nějaké alternativy? Viděl jsem např́iklad městské zahradničení (urban gardening). Jak ho hodnotíte?

F. Hammer: V kontextu krize největší korporace využily situace. U nás máme jednu takovou, která získala své bohatství díky půjčkám, a nyní zakoupila devadesát administrativních budov v centru Detroitu. Vlastníkem je jen jeden člověk. Cena těchto budov byla nízká. On a další mají novou vizi budoucnosti Detroitu.

M. Hrubec: Jmenovat v tomto prípadě může znamenat zostudit. Můžete ho jmenovat?

F. Hammer: Jeho př́jmení je Gilbert. Vypráví se vtip, že Detroit si své jméno změní na Gilbertville. Lidé, kteří byli vyhozeni z domů, se mezitím snažili přežít. A jedním z těchto hnutí bylo hnutí za přístup k jídlu, jehož součástí bylo městské zahradničení, které jste zmínil. To bylo spojeno s další událostí, k níž v Detroitu došlo, které se proto začalo říkat „poušt' jídla“. Není totiž možné v obchodě nakoupit čerstvé jídlo, čerstvé ovoce a zeleninu. Všechno je upravené a zabalené. A protože v Detroitu je hodně volné půdy, někteří jeho obyvatelé si tuto skutečnost spojili s výše uvedeným nedostatkem př́stupu k čerstvému zdravému jídlu a začali budovat potravinové hnutí. Ve městě tak vzniklo hodně zahrad různých velikostí, které zásobují komunity potravinami a prostřednictvím tohoto zahradničení zároveň budují komunitu.

M. Hrubec: Jsou to jednotliví zahrádkáři, nebo skupiny, družstva? Existuje spolupráce mezi zahrádkáři?

F. Hammer: Existují jak jednotliví zahrádkáři, tak skupiny. Znají se navzájem a uvědomují si, že jsou součástí většího hnutí. Tak např́íklad v oblasti Detroitu existuje afroamerická potravinová sít', která se stará o přežití lidí ve městě a zároveň tam také buduje sociální sítě a komunitu, protože jinak by zde žili lidé bez jakékoli naděje. 
M. Hrubec: Byl jsem překvapen, když jsem viděl zahrady nejen na předměstí, daleko od centra, ale i prímo v centru.

F. Hammer: Ano, je tomu tak. Četl jsem nedávno článek jedné ženy, která strávila tři roky v zahrádkářském a farmářském hnutí. Uvedla: „Byla to opravdu skvělá, výborná zkušenost, ale nebyla jsem schopna si tím vydělat na živobytí." Zde se nám ukazuje problém. I když farmářské hnutí dává lidem podporu a smysl, není udržitelné z ekonomického hlediska, což je ale dnes potřeba. Někteří lidé se domnívají, že by se farmaření dalo vykonávat takovým způsobem, aby bylo výdě-lečné a vydělalo se jím na živobytí. Vím, že se zde názory liší. Vznikli malí podnikatelé, kteří si otevřeli obchod na kola nebo dělají různé drobné věci, aby se uživili. Po krachu Detroitu začaly velké korporace a jejich nadace podporovat podnikání, aby do Detroitu přitáhli městské mladé lidi bílé pleti. Mohli by využít nízkých cen nemovitostí a bytů a začít podnikat. To však s sebou nese gentrifikaci. Na domech v mnoha oblastech centra, které roky obývali černoši, se náhle objevují cedule s výpovědí: „Omlouváme se, ale budete muset opustit toto místo a najít si bydlení někde jinde. Budeme renovovat tyto budovy, abychom sem, do těchto nově zrekonstruovaných, a tudíž dražších prostor, přivedli bělochy z předměstí." Toto se dnes děje v Detroitu. Vidíte, jak je černošská populace ohrožena gentrifikací, odpojováním vody, výpověd’mi. To vše vede ke krizi v černošské populaci.

M. Hrubec: Vím, že některé předměstské části jsou víceméně opuštěné a mnoho domů zde už bylo zbouráno.

F. Hammer: V oblasti mezi osmou až desátou mílí od Detroitu došlo k úpadku bělošské dělnické populace. Nedošlo k tomu v tak výrazné míře jako u černošské populace, ale přesto to bylo výrazné. $V$ daném pásu také najdeme mnoho opuštěných prostor. Podobné je to také na jihozápadě Detroitu: zde existoval silný ocelářský průmysl, který je však nyní v úpadku.

M. Hrubec: Jak vidíte budoucnost pracovní síly v automobilovém průmyslu? Dochází k automatizaci a nebude patrně potřeba tolika dělníků. Dnes ještě zakoušíme důsledky krize, ale ty nebudou trvat věčně. Lidé zase začnou více nakupovat auta a vlastníci automobilového prümyslu budou profitovat. Myslím si, že tento zisk by měl být lépe rozdělen, aby se nekumuloval jen v rukou malé menšiny lidí. Jak dnes vypadá redistribuce a jak by podle Vás měla vypadat?

F. Hammer: Jedním z jevů, k nimž došlo ještě před bankroty, ale samozřejmě pokračují i po nich, je vytvoření tří vrstev dělníků v automobilkách. V jedné továrně najdete u stejné práce dělníky, kteří stále pracují za 28 dolarů na hodinu, jiní však už za 15 dolarů a další pouze za 8 dolarů. 
M. Hrubec: Jaká je výše minimální mzdy?

F. Hammer: Je to 8 dolarů na hodinu. Někteří dělníci nejsou zaměstnanci automobilky, kteří by byli př́mo zaměstnáni firmou, ale pracují pro subdodavatele. Za těchto 8 dolarů vykonávají práci jako najatí agenturní pracovníci. Existuje však hnutí, které se snaží prosadit zvýšení této mzdy. V automobilovém průmyslu tak nacházíme dělníky, kteří se trochu podobají zahraničním dělníkủm tím, že si také nemohou dovolit koupit auto, které vyrábějí.

M. Hrubec: A co si myslíte o klesajícím počtu dělníků v automobilovém průmyslu kvůli automatizaci?

F. Hammer: Továrnu, kde jsem pracoval, opustilo 400 dělníků, a to jak kvůli tomu, že se práce přesunula jinam, tak také kvůli automatizaci. Obhajoval jsem, spolu s některými dalšími zaměstnanci, ale bohužel bez úspěchu, projekt vytvořit z uzavřených továren montovny dílů do větrných turbín či solárních panelů, př́ipadně jiných zařízení, a reagovat tak na současnou environmentální krizi a změnu klimatu. Zajistila by se tak znovu práce $\mathrm{v}$ továrnách a vyráběly by se užitečné věci.

M. Hrubec: Ano, zdá se, že ekonomická demokracie, tedy zaměstnanecká demokracie, by byla spravedlivá a produktivní. Obama se presto vydal jiným směrem. Zaměřil se na ekonomickou krizi, ale dopady této snahy nebyly př́liš úspěšné, protože se nestaral o továrny v USA, jak jste již řekl. Snažil se např́klad podpořit solární, zelený byznys $v$ USA, ale důsledkem je, že největším výrobcem solárních panelů na světě se stala Čína, protože americké společnosti pro tuto výrobu vybudovaly či začaly využívat továrny $v$ Číně.

F. Hammer: To jste řekl výstižně. Řeknu Vám další př́́klad. Před několika lety byla na předměstí uzavřena jedna z továren Fordu, která vyráběla Lincolny. Dvě společnosti chtěly továrnu koupit. Jedna zde plánovala vyrábět větrné turbíny, druhá solární panely. Odbory, stát i město v něčem ustoupily a prohlašovaly: „Ano, chceme zde tyto firmy a uděláme pro to všechno.“ Jediným důvodem, proč se to nakonec nerealizovalo, bylo, že federální Úřad pro energetiku neposkytl garanci na půjčku pěti set milionů. Továrna tak byla zavřena a výše uvedené produkty se vyrábějí v zahraničí.

M. Hrubec: To je globalizace.

F. Hammer: Ano. A je to také krize v tom smyslu, že lidská práce se stává přebytečnou. Nepotřebujeme již dále tolik lidské práce.

M. Hrubec: Myslíte tím Západ?

F. Hammer: Ano. 
M. Hrubec: Ale nebude to kvůli automatizaci v budoucnu stejné i na mnoha jiných místech?

F. Hammer: Ano, samozřejmě.

M. Hrubec: Jaká jsou možná řešení? Vidíte nějakou alternativu? Uvažujete také o nějakém politickém řešení, které by bylo spojeno s ekonomickým? Kterým směrem byste doporučil se vydat?

F. Hammer: Domnívám se, že se musíme zaměřit na environmentální krizi, která je vytvořena tím, jakým způsobem funguje kapitalismus. Zabíjíme oceány a ohřriváme planetu emisemi uhlíku. Zdá se, že celé lidstvo by se mělo velmi koncentrovaně zaměřit na tento problém, protože, jak čas běží, problém se zhoršuje. Např́iklad v našem městě je třeba rekonstruovat všechny budovy, aby byly efektivnější ve využívání energie, a tím snížily její spotřebu. A to by zároveň vytvořilo zaměstnanost. Jediná věc, která tomu brání, je nedostatek politické vůle. Je proto třeba vytvořit politické hnutí, které by spojilo dohromady mnoho různých skupin. Jak to provést? Mluvili jsme o roli odborů a Vy jste se mne zeptal: „Měly by se odbory starat skutečně jen o své členy?“

M. Hrubec: Ano, to je částí řešení. Problémem oborů v minulosti bylo, ale je to problém často i dnes, že se starají pouze o své členy. Co ale s těmi, kteří jsou vyhozeni z práce, nezaměstnaní či mladí lidé, kteří ještě nikdy zaměstnáni nebyli? Odbory by se měly, alespoň částečně, zajímat i o ně, komunikovat s nimi, spojit se s nimi a řšsit problémy společně.

F. Hammer: Správně. Musíte si položit otázku, proč by měli být dnes dělníci, kteří pracují v továrnách General Motors, spokojeni s platem 8 dolarů za hodinu? A odpovědí je, že je dnes velmi těžké získat práci. Odbory si musí uvědomit, že nemohou zlepšit situaci svých členů, aniž by bojovali i za nezaměstnané.

M. Hrubec: Odbory by tak měly být, pokud Vám dobře rozumím, součástí řešení problémů, včetně environmentálního.

F. Hammer: Správně. Podniky by měly mít povinnost recyklovat již nepoužívaná auta. V USA však nic takového neexistuje.

M. Hrubec: To by znamenalo regulaci trhu.

F. Hammer: Ano. Ale co doopravdy potřebujeme, je hnutí, které se zaměří na samotný kapitalismus.

M. Hrubec: Máte na mysli oslabení soukromého vlastnictví a rozšírení veřejného vlastnictví?

F. Hammer: Ano, je třeba rozšíríit veřejné vlastnictví. Před pár lety jsem navštívil Johannesburg v Jihoafrické republice a setkal jsem se se zástupci odborů 
hutnického průmyslu (NUMSA). Pořádali schůzi o zelené energii a tvrdili, že jejím předpokladem je veřejné vlastnictví, ke kterému proto musíme směřovat. A i když má Jihoafrická republika stodvacetiletou tradici těžby uhlí, přesto říkají, že dnes musí přejít na zelenou energii a že k tomu může dojít jen za podmínky veřejného vlastnictví.

M. Hrubec: Máte na mysli specifický druh veřejného vlastnictví, nebo pluralitu vlastnictví na různých úrovních - lokální, státní, federální?

F. Hammer: Myslím veřejné vlastnictví na různých úrovních. V Jihoafrické republice jsem se dozvěděl, že tam existují také komunity, které mají kontrolu nad zdroji energie ve své komunitě. $\mathrm{Z}$ toho mají prospěch a mohou také energii prodávat mimo svou komunitu. Tímto směrem bychom se měli vydat.

M. Hrubec: Nevíte, jakou má dnes v USA podporu socialismus? Zdá se, že čím dál více lidí je nespokojeno s oligarchickým dvoustranickým systémem a chtějí alternativu.

F. Hammer: Když hnutí Occupy dosáhlo svého vrcholu, nastaly dvě zásadní věci. Změnil se způsob, kterým lidé hovořili o USA. Najednou jsme mluvili o jednom procentu proti 99 procentům, a to proměnilo diskusi v USA jako nic jiného. Stalo se to součástí slovníku. Toto hnutí jako jediné se opravdu zaměřilo na Wall Street a kapitalismus. Máme také zprávy z průzkumů veřejného mínění, které ukazují, že mladí lidé dnes upřednostňují socialismus před kapitalismem.

M. Hrubec: Myslíte v USA, v sociologických průzkumech?

F. Hammer: Ano. Nikdo dneska neví, jak si všichni tito lidé socialismus představují, ale tito lidé cítí, že socialismus je lepší alternativa než to, co v současnosti máme. Socialistické hnutí, které je dnes velmi malé a rozptýlené, si musí uvědomit své př́ležitosti a musí prorazit tabu, které se okolo socialismu vytvořilo. Musí za něj bojovat, učinit ho populárním, známým; nesmí být uzavřené.

M. Hrubec: $V$ rámci hnutí Occupy byli lidé, kteří se o to pokoušeli. Co si myslíte, jaký poznatek si můžeme odnést z tohoto hnutí, i když nakonec skončilo? Pokud budeme vědět, jaké byly jeho pozitivní i negativní stránky, lze se z nich poučit a přiště lépe vědět, jak jednat.

F. Hammer: Toto hnutí nakonec neuspělo, ale mnoho lidí, kteří byli jeho součástí, získalo zkušenost s jinou politicko-sociální strukturou. Hnutí se pro ně stalo tréninkovým místem. A mnoho z nich je zde v Detroitu zapojeno do hnutí odmítajícího výpovědi z bytů, jiní se zase angažují v environmentálním hnutí. Hodně lidí, kteří prošli zkušeností v hnutí Occupy, se tak poté zapojilo do jiných hnutí.

M. Hrubec: Hovorríte o tom, že hnutí Occupy bylo jedno hnutí a že nyní existuje pluralita aktivit a organizací. To tedy znamená, že dochází z rozšiřování občanské 
společnosti a veřejnosti. Můžeme říci, že hnutí Occupy zaniklo, aby zrodilo pluralitu aktivit a organizací?

F. Hammer: Správně, k tomu dochází. Bylo to dobře vidět, když hurikán Sandy udeřil na východní pobřeží New Jersey. První, kdo reagoval, nebyla policie, hasiči ani úřady, ale hnutí Occupy. To, po této hrozné bouři, pomáhalo lidem, organizovalo různé činnosti a zajišt'ovalo potřebné věci.

M. Hrubec: Dochází tedy k proměnám názorů. I když lidé nejsou na ulicích, nestávkují, myslí jiným způsobem, delegitimizují systém svým každodenním životem, ve svých každodenních bojích za spravedlnost.

F. Hammer: Ano, myslím si, že to je pravda.

M. Hrubec: Připravují tedy podmínky pro další změnu.

F. Hammer: Je to tak. A nyní si položme otázku, proč hnutí Occupy skončilo? Pravděpodobně z toho důvodu, že strategií bylo okupovat veřejný prostor, který nevyhnutelně nemohlo být schopno udržet. Pokud okupujete veřejný park nebo prostor ve veřejném vlastnictví, pak vás z něj úřady nakonec vyženou. Taktika hnutí byla přesvědčivá, ale nutně měla krátkou životnost. Otázkou je, jak zabrat veřejné vlastnictví na delší dobu. Nikdo na to ještě nepřišel.

M. Hrubec: Myslíte si, že krize víceméně skončila, nebo budeme čelit postkrizovým problémům, které povedou ke kolapsu, přinejmenším v USA?

F. Hammer: Víme, že krize jsou cyklické, že k nim periodicky dochází.

M. Hrubec: Myslíte si, že krizový cyklus již skončil?

F. Hammer: Nemyslím, je tomu spíš naopak. Předpovídám, že dojde k další krizi. Jedna z věcí, která je podstatná pro éru bankrotů v Detroitu, spočívá v tom, že došlo k opatřením, která brání návratu demokracie do města. To je nyní kontrolováno cizími lidmi.

M. Hrubec: Koho těmi cizími lidmi myslíte?

F. Hammer: Komisi zástupců korporací, která má ted' konečné slovo při rozhodování o Detroitu.

M. Hrubec: Co byste doporučil lidem v této situaci dělat? Co je ted' nejdůležitější?

F. Hammer: Odpověděl bych tím, co ted' dělám. Jednou z věcí, o kterou se ted' pokouším, a domnívám se, že je velmi důležitá, je vytvořit globální jednotu, globální solidaritu. Nepřítel, se kterým zápasíme, je globální. Musíme se proto spojit a jednat globálně ve vztahu ke globálním korporacím. Musíme se spojit a prohlásit: „nikdy více“, at’ již je to v Latinské Americe, nebo zde v Detroitu. Tváří tvář 
globálním hrozbám, kterým čelíme, si musíme uvědomit, že lidé začínají vytvářet jiné mocenské uspořádání. Ale to nevytvoříme, pokud se nespojíme.

M. Hrubec: Globální problémy vyžadují globální řešení.

F. Hammer: Správně. Globální kapitalismus vyžaduje globální kritický přístup. To se dotýká druhé věci, kterou se zabývám. Snažím se propojit s ostatními, abychom čelili klimatické změně, protože ta je také globálním problémem. Nemůžeme řešit klimatickou krizi pouze zde v Detroitu. Náš př́stup se také stane efektivnější, když se spojíme s ostatními a nebudeme se soustřed’ovat jen na klimatické problémy, ale zaměříme se obecně na celou environmentální krizi. Je třeba globální odpovědi a musíme si také uvědomit, že i když čelíme spoustě rozdílných problémů, environmentální katastrofě musíme čelit společně. To je druhá věc, které se nyní věnuji. A třetí věcí je boj za demokracii. Zdá se mi, že lidé nebrání demokracii.

M. Hrubec: Protože je pouze formální.

F. Hammer: Přesně tak. Domnívají se, že nic nezmění. Za těchto podmínek mohou elity přijít a říci: „Ted' kontrolujeme Detroit“ - a nikdo na to nic neřekne. Toto jsou tedy věci, které se nyní snažím prosadit.

M. Hrubec: Měli by být lidé více aktivní?

F. Hammer: Měli by se angažovat. Je jasné, že korporátní média se snaží veřejnost pacifikovat, aby si toho, že přišla o svou moc, nebyla vědoma. Proto potřebujeme mnohem více rozvinutá sociální média, která...

M. Hrubec: ... by mezi lidmi šiŕrila kritické myšlenky.

F. Hammer: Ano. A právě z tohoto důvodu se domnívám, že je toto interview důležité.

M. Hrubec: Děkuji Vám za rozhovor. ${ }^{1}$

${ }^{1}$ Text rozhovoru z anglického do českého jazyka přeložil Martin Brabec. Jazykovou redakci českého jazyka provedla Alena Bakešová. Orig.: Hammer, Frank/Hrubec, Marek: The Decline of Industrial Detroit. In Perspectives on Global Developmentand and Technology 15 (2016), 63-83. Brill. 